\title{
Gender and Human Rights: The Girl Child and Violence
}

\author{
Dr Jane Nkechi Ifechelobi
}

Department Of English Language and Literature, Nnamdi Azikiwe University ,Awka

\begin{abstract}
Violence is an act that causes pain, suffering, societal prejudice, humiliation, ostracism, marginalization or even death. Any action carried out intentionally or unintentionally but which affects an individual negatively in an injurious or destructive manner maybe perceived as violence. Violence may be political, social, emotional or religious depending on the situation surrounding a given society. Any form of violence is an abuse of human rights which restricts or denies an individual access to his or her rights in society. Such universal basic rights are rights to live, freedom of thought, speech or religion, freedom of movement, choice, acceptance and security. Unfortunately the girl-child has suffered most in our society, both within the family and other social institutions that are meant to train, educate and socialize her. The girl-child in many African societies, Nigeria not exempt, has been sexually abused, trafficked, denied education, humiliated, oppressed and suppressed. She has been subjected to various forms of gender-based violence such as domestic violence, cultural violence, rape, forced prostitution and forced early marriage. These impinge on the growth, rights and physical well being of the female gender especially the girl child, with huge and grave consequences. The thrust of this paper is to see the extent the girl-child has been exposed to violence, how far she suffers and is still suffering from one form of violence to another. The paper concludes that despite the violence prohibition Act of 2015 the girl-child is still very much subjected to violence and if definite steps are not put into action the girl-child will continue to be deprived of her rights.
\end{abstract}

Keywords- Human Rights, Violence, verbal abuse, threats.

\section{INTRODUCTION}

Violence is a very complex subject which takes frightening dimensions in different societies of the world. Violence can be physical, which can result in bodily harm, verbal abuse, threats or deprivation. It can also present itself sexually or culturally, depending on the situations surrounding a given society. The term 'violence' according to World Health Organization is 'the intentional use physical force or power, threatened or actual, against oneself, another person, or against a group or community, which either results in or has a high likelihood of resulting in injury, death, psychological harm, mal-development or deprivation'(2012). The above definition echoes the views of violence prevention Alliance on the World Report on Violence and Health (WRVH) which stipulates the types of violence or various ways to understand the contexts in which violence occurs. Hence, suggesting that violence can be inflicted through physical attack (sex abuse), psychological attack and or deprivation.

Violence against women is a global concern. Global violence uniquely affects the girl child. Although international legal instruments have been in place for decades to protect the girl-child, thousands of brutal acts of violence and neglect has been observed around the world on daily basis. It is an action that causes pain , suffering, loss of self-esteem, or even death. It is also note-worthy that the problem of violence is not new in Africa or in our societies and many have cried out for lasting solutions yet the problem is still here with us. Violence of any sort is an indication of an abuse of human rights which restricts or denies an individual access to ones rights in society. Such rights as-the right to live, freedom of thoughts, religion or speech, freedom of movement, freedom of life, freedom of choice, of sexual orientation, acceptance and national security. Physical and psychological violence against the girl -child occur both in public and in family circles. Many of these atrocities are not reported for fear of shame and/stigmatization.

\section{GENDER-BASED VIOLENCE}

Gender-based violence is primarily violence committed against the female gender. According to Article 2 of the United Nations Declaration on the Elimination of Violence Against Women:

Violence against women is a manifestation of historically unequal power relations between men and women and that violence against women is one of the crucial social mechanisms by which women are forced into a subordinate position compared with men.(2)

Colomba Kaburi Muriungi et al reiterate that 
Gender-based violence is therefore an umbrella term for any harm perpetrated against a person's will and it could be physical, sexual, psychological,

economic, or socio-economic .Violence is therefore a means of control.(117)

Consequently any act committed in public or private based on gender which causes injury, suffering, humiliation or death is referred to as gender-based violence. Forms of gender- based violence can manifest in: oppression, child abuse, stigmatization and various forms of injustice. Unfortunately the girl-child is incapacitated as how, and who to run for help.

The Gender in Nigeria report of 2012 indicated that young women between the ages of 15 and 24 were the most likely to experience violence but the truth of the matter is that because most of these acts of violence are not reported there is no authentic statistics. Going by newspaper reports of some of these incidents we know that the ages of some of these victims of acts of violence are sometimes unimaginable because some babies have suffered sexual violence even in the hands of relations.

\section{THE GIRL-CHILD}

It is important to define the girl-child for the purposes of this work. Any of the human female gender from birth through childhood to adolescence will be termed the girlchild since she has not attained womanhood. The girlchild is therefore described as a female child between infancy and early adulthood. During this period of development the girl-child is supposed to be in the custody and supervision of parents, guardians and older siblings. She learns by observation and counselling and therefore gains proper maturity -physically, mentally, psychologically and otherwise. It is also a period of innocence, ignorance, exploration and of education At this period she is easily influenced and trusts people around .It is a critical period in her development because she could easily be harmed and deceived. The girl-child is always at a greater risk than the male counterpart. She is entrusted with looking after her younger siblings, performs house hold chores at a very tender age, serves as maid to other families, hawks wares, serves as sales girl and when men engage in secret and demonic cults and need to make human sacrifices it still the female parts of a human being that their gods accept. In fact the girl-child is an endangered species.

\section{THE VIOLENCE AGAINST PERSONS (PROHIBITION) ACT, 2015}

The Violence against Persons (Prohibition) Act, 2015 which was signed into law in Nigeria on the $25^{\text {th }}$ of May gives a broad definition of violence. "'Violence in this Act, "'means any act or attempted act, which causes or may cause any person physical, sexual, psychological, verbal, emotional or economic harm whether this occurs in private or public life, in peace time and in conflict situation" (1). The above definition is all embracing as it tries to capture every form of violence against men, women, and children as well as political violence et cetera. Furthermore, being a national law, its provisions extend overarching protection against violence throughout the country.

More importantly, for the purpose of violence against the female gender, the Act prohibits female circumcision/female genital mutilation (FGM), forceful ejection from home and harmful traditional practices. It also prohibits the abandonment and exploitation of women, men, children and other violence acts such as battery and sexual abuse. Previously, this practice was not specifically banned by law in many parts of the country as a result of cultural difference which characterize different religions in Nigeria. Thus, there was no general legal prohibition throughout the country, as such people suffer one form of violence or the other. Such general prohibition is very necessary because some of these practices impinge on the rights and physical well-being of individuals which might also affect the society with huge consequences. In addition to the fundamental human rights stipulated in the constitution, victims of violence have their rights protected under the Act. They are also entitled to compensation for harm done to them or to family members or for any loss incurred as a result of violence by the perpetrators. But the fact remains that cases of violence are not reported as a result of various reasons which might lead to stereotype, humiliation or death of the victim.

Violence is an action which causes pain, suffering or destruction whether it is intentionally committed or not. Therefore, any action carried out consciously or consciously which affects an individual negatively in an injurious, psychological or destructive way may be perceived as violence. It is in fact important to note that the problem of violence is not a new issue in Africa and the world general. Consequently, many scholars from different social groups, governors, NGO'S, some First Ladies have been grappling with the issue of violence which has endangered the lives of many in society with a view of finding a lasting solution; yet the problem continues unabated. Hence, one can compare violence to a deadly monster which has many tentacles to grab or inflict pain on any human being especially the girl-child, depending on the social condition surrounding the individual. This is an indication that violence of any form is an abuse of human rights which restricts or denies an individual access to his or her rights in society. Such universal basic rights are: rights to live, freedom of 
thought, religion or speech, freedom of movement, freedom of life, freedom of choice, freedom from slavery, freedom of sexual orientation, acceptance and national security etc.

Physical and psychological violence against the girl-child occur both in public and within the family circles. The family and other social institutions are meant to train, educate, and socialize the girl-child without exposing her to any form of violence, but the reverse is the case as some members of different social groups contribute in harming the girl-child in one way or the other.

In most Africa societies, reliable data on violence against girl-child is scarce because violence is often not reported as it occurs mostly within the context where it is usually concealed such as within the family circle, behind the privacy of homes, in war prone zones or terrorized environment. The predominant cultural belief in some African societies is that girl-child must be submissive to their guardians, elders, customs and traditions even when they are exploited, abused and denied their freedom; therefore any behaviour that is not in conformity with the above view is unacceptable. It is apparent therefore, that the aftermath of different forms of violence results in the denial of girls' right or freedom.

\section{VARIOUS FORMS OF GENDER-BASED VIOLENCE}

Gender-based violence in this excerpt refers to the different forms of violence the girl-child suffers. Over the years not only in Nigeria but also in the world over, especially in Africa the female gender has been facing all forms of dehumanization, maltreatment, exploitation, oppression, humiliation, subjugation, negligence and even isolation.

For the purposes of this paper, only three types of genderbased violence will be discussed-viz

Domestic Violence

Sexual Violence

Cultural Violence

\section{DOMESTIC VIOLENCE}

In the National Demographic and Health Survey (NPC) and ICF Macro 2009, Nigeria has one of the highest rates of domestic violence in Africa.

Most often we read in newspapers of children that are brutally manhandled- Many of these children suffer in the hands of family members who have taken them up as maids or in the guise of trying to help them and especially children from poor families. At the slightest provocation such girl-child is traumatized, frustrated, bullied, etc denied certain rights - for example education, good nutrition, entertainment, clothing etc Many are punched, abused, spat at - yet they keep quiet.
She may not be sent to school, and even if she does, she may not learn much because by the time she reaches school other children may have done one or two lessons. Again, the weakness of the body may not help her to concentrate, being the only one that handles the household chores, the last to go to bed and the first to wake up.

Domestic violence sometimes makes sure the child is punished beyond whatever crime she has committed. Imagine where a girl-child in primary six is given fifty strokes of the cane. A father used hot pressing iron to scald two of his children on their stomachs because their step-mother accused them of stealing fish from her stew pot.

A woman used razor blade to put severe cuts on the body of her maid. Many of these maids have gone home with several indelible cuts/marks on their bodies. One poured acid on her maid. Some are dressed in rags or oversize clothes. Many go to bed on empty-stomachs, if they must eat, they have to pray that the bread would go stale or the soup sour.

Shockingly, most of these girls and their families endure and sometimes die in silence believing that there is no where to get justice.

According to Animasun, Denrele Domestic Violence affects not just the victim but indirectly all those who witness the violence: children- family, relatives and witnesses to the physical abuse and violence. It predisposes the children to trauma and other psychological problems throughout their lives and worryingly: they may learn to become future victims or abuses later on in life and hence the cycle continues-Page 16 Sunday Vanguard July 30, 2017

\section{SEXUAL VIOLENCE}

Cases of sexual violence against the girl-child in Nigeria have disturbingly become a regular feature in the dailies. We often are confronted with such bizarre stories such as this: Five students of Adeyemi College of Education, Ondo and Giwa Polyttechnic, Owo rape a female student and recorded the criminal activity to blackmail their victim into silence.(Vanguard Newspaper -July,23 ${ }^{\text {rd }}$ 2017) Again, the girl-child is at the centre of this crime. Okoroafor,Cynthia quoting Jose Foundage claims that six out of every Nigerian child under the age of 18 years experience one form of physical ,emotional and sexual violence before the age of eighteen. Under sexual violence many are raped by the people that are expected to guide, teach, love, cherish and protect them. Such people are fathers of the victims, older relatives (blood brothers/ nephews/cousins) etc; teachers in the school, friends, neighbours and peer-groups and of course strangers. 
It is a fact that many a girl child is used to hawk waresfood items etc to make ends meet and many in the bid to help their families financially are lured by people pretending or promising to buy all they have to sell and so rape them, at building sites, uncompleted buildings, or in the markets even in stalls. Many housemaids are regularly raped by their employers. Even in primary schools teachers rape their pupil.

According to Babajide Alabi: In Africa, it is not often we get to talk about rape. This is saying it mildly, because we rarely talk about it. When we do, it is done in whispers and in private clusters, never to be discussed publicly. Aside this, it is also a taboo, that comes up only when someone close is involved. The resultant effect of the loud silence is victims are indirectly turned into the accused. (Page 12 Vanguard: Sunday Sept 17.2017)

There has been numerous reports of children and even infants suffering from such dastardly acts. One prominent case, being the rape of a six month old baby .The incident took place in Kano State.

Others culled from some newspapers have such news as: *Feb.2017 -a 20 year old cobbler sexually assaults five year old in Lagos

*March 2017-55 year old man rapes seven old step child in Katsina.He drugged his new wife to commit the wicked act.

*May 2017-3men gang rape a one year old in Katsina.The men snatched the baby from the mother's back and fled into the bush and raped the baby until she fell into a coma.

*May 2017-14 year old rapes 7 year old in Lagos.

*June 2017- 20 year old rapes deaf girl in Ogun.

*June 2017-Man rapes 13 year old girl and infects her with HIV.

*June 2017 -16 year old rapes an infant-1year\&4months in Ebonyi State.

*70 year old man rapes six year old orphan repeatedly for four years.(Sunday Sun-30 ${ }^{\text {th }}$ September,2017)

* Man rapes daughter and maid (http://pmnewsnigeria/2012/04/26)07oilhi,

Some girls are lured into prostitution in foreign lands. The pathetic case of Florence was trafficked at the age of 17 years to Russia by no other person than her Pentecostal pastor.

In her story -Sunday Vanguard of July 9,2017 the girl states thus:

It all started in 2012 when a
pastor_in my church called me
to say he wanted to see me. He asked me if I will
like to travel out of the country .I told him that I
was constrained financially; so he said money

was not the problem and that the sister abroad will finance the trip. He further told me that I could pay off in less than two months after my arrival abroad. He added that I shouldn't be afraid of making money abroad since I am a good singer and hair stylist(16).

The girl was also molested and raped by the person that picked her up in Lagos for two weeks. During the interview with the Vanguard Newspapers she disclosed that many of our young girls out there have died while back home the parents think they are alive. She also revealed that out of the 300 girls deported in the last one year, about 100 of them are HIV positive.

Due to the astonishing rate of sexual violence the Senate passed a motion tagged: Urgent need to investigate the alarming rate of rape and sexual assault against women, children in May. Unfortunately only very few out of the 36 states in the Federation has done something. In Lagos State for example an awareness walk was organised at Epe Local Government Area of the state. The aim was to raise awareness and sensitise residents on the dangers of domestic and gender-based violence, child-abuse and rape. The Lagos State Domestic and Sexual Violence Team (DSVRT), has taken the campaign against domestic and gender-based violence to the grass root. The coordinator Vivour-Adeniyi said the State government would not rest until incidents of sexual and gender -based violence are brought to zero.

Commenting on Nigerian students Imoka on Vanguard newspapers of August 17,2017 cried out against the ongoing sexual violence in schools. She lamented that many of the girls are dehumanized, denigrated and depleted by our educational system. They are subjected to sexual violence and all forms of harassment by their teachers. Across the nation, innocent girls in public and some private schools are molested by administrators and made to succumb to impossible choices of immoral relationships or they fail. Some loose their lives in a bid to get rid of unwanted pregnancies or become drop outs so as to nurse babies, having become mothers at an unripe age.

\section{CULTURAL VIOLENCE}

Unfortunately in the African culture the female gender is meant to be seen and not to be heard. She is subjected to all forms of humiliation. In some of our societies today there are certain types of food especially meat which the female gender must not eat. She must sit in a particular way, dress in a particular manner and speak in a particular way. Achebe portraying our culture in one of his novels:the protagonist- Okonkwo shouts on Ezimma "to sit like a woman." 
Beyond this, the female gender is not allowed to inherit property, so if a man dies without a male child, all he laboured for goes to his brothers in some communities the wife is deprived of all the man's property. In some, one of girls may be denied the opportunity of getting married. She stays in her father's house to procreate so as to maintain the family lineage. Some girls no matter how brilliant they are, are denied education, for the simple reason that they are girls and will in the nearest future end up in a man's kitchen, so training her academically" is a waste of money."

Early marriages are still practiced in most parts of the country, unfortunately these girls in their tender ages are married by men old enough to be their fathers if not grand-fathers. Some of the girls are married off against their wish.According to Uwais a gender activist "child marriage is the worst form of violence against the girlchild .Such children below the ages of 18 are both physically and physiologically deficient to shoulder the responsibilities of marriage and child bearing. They are deprived so much in life and so help to contribute to intergenerational poverty in society.The child-bride is left uneducated ,immature and unprepared to take decisions and address issues of family life. Currently a senator married a thirteen year-old girl. They are the men the girlchild is expecting to handle her case. Today many of these kid-wives are suffering from Vesico Vaginal Fistula-VVF-a condition that makes them leak urine or faeces or both. Stories abound of rejection and mental frustration of these helpless girls. According to Obinna-

"Between 120,000 and 150,000 Nigerian women and girls live with the despicable disease"(Sunday Vanguard,August,20,2017)

Studies have also shown that cultural beliefs of marriage and conception at a very young age, often before full pelvic growth has been achieved, is the most prevalent causative factor of this dreaded VVF. It is disheartening to note that most often these ladies become stigmatized and dehumanized. The condition affects their emotional and psychological well-being and most often the people that caused their woes chase them out of their homes, they end up becoming homeless, hopeless, dejected, rejected, dehumanized, traumatized and frustrated.

In some societies the girl-child undergoes female genital mutilation rituals.Female Genital Mutilation is the partial or total removal of the external female genital organs for non-medical reasons. This act has done terrible damage to girl's organs as it causes severe pain and may result in prolonged bleeding, infection, infertility and even death. This is outright violation against the right of the girlchild.

\section{CONCLUSION}

According to World Health Organization in "World Report on Violence and Health: Violence is one of the leading causes of death in all parts of the world "(Krug et al ed.(2002)Many are injured, dehumanized and so suffer from a range of physical, sexual, reproductive and mental health issues. The activities of men and some women contribute to suppressing and violating the rights of the girl-child.

The girl-child has been traded, bought, and sold across national borders as commodities to be put to use as prostitutes or slaves or merely sold to make profit. Despite the worrisome situation of girl-child violence little or nothing is being done to arrest this ugly situation. All of us, especially the female gender should rise and take a stand against all types of violence and aggression against the girl-child. There should be planned public awareness in all the states of the federation which will be aimed at households, universities, communities, marketplaces, public and private offices. The girl-child should be encouraged to speak out against any act of violence whether at home, in the school or even in the church. Organisations such as FIDA, UNICEF,WHO, THE National Agency for the Prohibition of Traffic In Persons(NAPTIP) should all work towards protecting the girl-child. The Violence Against Persons Prohibition Act, 2015 which was signed into law on the $25^{\text {th }}$ of May 2015 must be made to work. Perpetrators should be brought to book and be made to pay heavy financially compensations for harm done or even be imprisoned.

\section{REFERENCES}

Animasun, Denrele. Vanguard Newspapers July 30,2017.

August, 17,2017

September, 17,2017

August,20,2017

World Health Organization(WHO)Sexual Violence.15 April,2015.

-----Violence.26 March 2017

Violence Prevention Alliance:Definition and Typology of Violence (WHO,2017)

Krug et al.World Report on Violence and Health.WHO2002.

Colomba Kaburi Muuriugi and Anne Kinya."An Analysis of Gender Based Violence in African Literature" in International Journal of Humanities and Social Science Vol.3 No 12 ,June 2013.

The United Nations(UN) Women Rights in Africa.'The Epidemic of Violence against Women in Africa.Sunday,April 09,2017. 